\title{
Legislation and Perception: Changes in Congressional Bills
}

Nicholas O. Howard, Auburn University at Montgomery

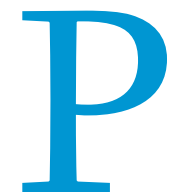
residential bill signings highlight years of effort by policy participants to pass their legislation into law. Such ceremonies often bypass the difficulties, intricacies, and maneuverings involved in how legislation reaches the president's desk, however. These maneuverings, referred to as procedural politics, provide structure and incentives at every step of the legislative process. What is often lost in descriptions of legislative success is how procedural politics often changes who wins, who loses, and who receives formal credit for legislation. My year working on Capitol Hill provided frequent evidence that minute details often constitute sources of conflict and success for these very reasons. Efforts to influence the legislative process dominated negotiations between offices, with offices often choosing between traceable success for their legislative actions and policy passage (Wilkerson, Smith and Stramp 2015; Krutz 2001). This experience stands at odds with treating whole legislative bills as the venue for success and productivity, as often reflected in research on the legislative process (Woon 2008; Ainsworth and Hanson 1996). Life on Capitol Hill demonstrates that bill passage often proves to be an inaccurate definition of success when considering an office's legislative priorities and the productivity of Congress as a whole.

This article discusses the challenges involved in translating legislative success into usable data. I first discuss why viewing legislation as the venue for success may be problematic for properly understanding and attributing success. The article then outlines ways to observe success in the legislative process consistent with my experience as an APSA congressional fellow. In what follows I utilize examples of legislative consideration during my time on Capitol Hill, and examples of marquee legislation from Congresses past, to illustrate the problems with attributing legislative success from data on the share of members' bills enacted into law. I also provide thoughts for studying legislative outcomes consistent with my own experience as a staffer that I hope prove enlightening to others.

\section{THE FY 2017 NATIONAL DEFENSE AUTHORIZATION ACT}

Among the last pieces of legislation signed by President Obama during his eight years in the White House, the "National Defense Authorization Act for Fiscal Year 2017," stands out for several reasons. The FY2017 National Defense Authorization Act (FY 2017 NDAA) marked the 54th consecutive year that the Senate Armed Services Committee has produced an NDAA.
This bill included some of the most intense legislative battles during my time in Congress. Due to its status as a committeeoriginated bill, Senator John McCain (R-AZ) controlled the bill by introducing it as a Chair's Mark in his role as Chair of Senate Armed Services. This meant that Chairman McCain could gather input from member offices when developing the bill prior to introduction as a committee originated bill with himself as the sponsor. Committee members did receive some advantage in this process due to their institutional positions, but non-committee members also submitted many requests for inclusion in the mark. After finalizing the bill, the Armed Services Committee sent the FY 2017 NDAA to the Senate floor for further consideration on May 18, 2016. This bill contained many hallmarks we have come to associate with Senate floor consideration. Closing debate on the first obstruction opportunity through filing cloture on the motion to proceed was almost immediate, and successfully invoked 98-o. Controlling debate proved unwieldy after this first vote, however. Senators targeted this bill with an array of amendments during debate. Six-hundred fourteen amendments were submitted during debate, with only two senators-Alexander (R-TN) and Coats (R-IN)-failing to submit at least one. A large discrepancy between submission and proposal occurred, with only 24 out of the 614 originally submitted. Some of this discrepancy resulted from senators protecting their interests, as can be seen in the two failed cloture votes on amendments that would have limited the ability to offer various additions to the bill. Cloture was invoked on the bill almost a month after leaving committee. The Senate later returned to this bill when the House changed the entire text of the bill through an amendment, with cloture votes on both the motion to disagree with House amendments and the consensus bill.

What I found remarkable about deliberation on this bill and others is the limited reflection in political science. Familiar are depictions of recent "do-nothing" Congresses (Mann and Ornstein 2006) with declining productivity (Kelly and Grant 2008). Other scholars focus on individual legislators' productivity, emphasizing which members produce more successful bills (Volden and Wiseman 2014). These studies produce useful results, but my time working on Capitol Hill illuminated discrepancies between studies focusing on legislation and how offices define success and productivity. Despite numerous members' involvement prior to introduction, the amending behavior of 98 out of 100 senators, and the contention over which chamber's version of the bill would ultimately be sent to the president, only Chairman 
McCain receives any credit for this bill as a whole. No cosponsors and no Senate debate for the House-originated bill were recorded, providing evidence of no other member's involvement when treating the bill as a component of its sponsor and cosponsors. Further, modern versions of the NDAA include many portions-or titles-which may have been separate sponsors after they move into the other chamber. This arises most often when a member in the other chamber has a related or companion bill not passed in its chamber of origin or stalled in the alternate chamber. Congressional offices again face a choice of protecting their own legislation or pursuing policy goals. This might result in neither bill passing,

\section{Despite numerous members' involvement prior to introduction, the amending behavior of 98 out of 100 senators, and the contention over which chamber's version of the bill would ultimately be sent to the president, only Chairman $M c$ Cain receives any credit for this bill as a whole.}

bills in prior Congresses. These problems with attributing success and productivity when focusing on legislation complicate our understanding of Congressional activity and member behavior.

\section{CONGRESSIONAL LEGISLATION: DIFFICULTIES IN CREDIT}

Legislation's definition in both Congressional rules and scholarship as the vehicle by which policy proposals are moved is clear. However, its practical definition is much more fluid. An example of this can be seen in the content of the Patient Protection and Affordable Care Act in 2009. As shown in Wilkerson, Smith and Stramp (2015), this legislation combined several existing bills by multiple members invoking various procedural maneuvers. While Representative Rangel (D-NY) is listed as the sponsor when considering legislation as a whole, the bill as signed by President Obama changed dramatically from its original content. This example is not unique, as the PATRIOT Act signed by President Bush in 2001 contained elements from multiple, previously introduced bills. Despite these bills' inclusion in the final product, only Representative Sensenbrenner (R-WI) is listed as the sponsor of the bill signed into public law when treating these bills as data. Each of these bills, as well as countless others, were protected or modified in important ways by motivated members who do not appear when exploring who introduces or cosponsors legislation.

This leads Congressional offices to face a choice to preserve their legislation or protect their policy interest. This difficulty seemed to arise most often at three points in the legislative process during my time in Congress. First, offices can introduce the same legislative idea simultaneously through a stand-alone bill, an amendment to another bill, or insertion into a larger, third bill. An office may be willing to accept only one of these outcomes and use the others for bargaining leverage, or be willing to accept any outcome so long as their preferred text is passed. If an office sacrifices their stand-alone legislation to preserve their policy ideas, or vice versa, this leads to different perceptions of an office's effectiveness when treating whole bills. This disconnect exists although the same policy result can be achieved through each outcome.

Second, and equally problematic for both Congressional offices and legislative process-tracing, is that bills may change the companion bill passing in place of the chamber's bill, or a chamber's bill passing with a substitute amendment from the other chamber. Each possibility presents problems in identifying a member's involvement in data, as a different bill may be passed in place of the originally introduced piece of legislation. For example the Bipartisan Campaign Finance Reform Act of 2002 signed by President Bush, referred to as "McCain-Feingold," was sponsored by Representative Shays (R-CT). Senator McCain (R-AZ) worked with the Houseoriginated bill and saw his policy goal signed into law, but only through sacrificing his own Senate-passed bill and obscuring the attribution of success in bill-level data.

Third, Congressional offices knowingly insert smaller legislative proposals into a larger bill to pursue their policy interests. In the NDAA example above, many offices attempted to preserve or expand long-held interests through small provisions inside the larger bill. These items included expanded base staffing, changes to land holdings for testing grounds, and material preservation. These individual items could have, and perhaps at one point in Congressional history would have, been separate bills. However, many offices worked inside the Chair's mark or through floor amendments to see their goals accomplished despite potentially diminished credit. These varied ways to achieve policy goals require a much more contextualized definition of success. Analyzing this contextualized success may require communication with offices to gather their interests prior to a session and comparing this to enacted policies post-session regardless of which bill contains an item or who sponsored the passed legislation.

These legislative battles have changed over congressional history. Earlier eras often saw legislation focused on relatively few items, with members pursuing their legislative priorities across many bills. Among the most successful senators for having their bills signed into public law served during and immediately after World War II, with their far more narrow bills passing the chamber in greater numbers. Bills such as the Affordable Care Act might have been multiple bills rather than a single legislative vehicle. Congressional rule changes also add to these shifts in priorities. The House now allows all members to cosponsor a bill, which was not true for much of the twentieth century. Designating special purpose funding through earmarks is no longer allowed under congressional 
rules, shifting constituent representation tactics to new areas. These and other changes provide differing incentives to current members.

Legislative fights occur hidden away in private negotiations and in plain view on the floor. Each is important to the success or failure of an office's legislative priorities and reputation, but not all appear equally in legislative data. Focusing on bills as the unit of effectiveness and efficiency can lead to overlooking important legislative battles and their changing contexts, looking instead at only the outcome of the strategies and fights. which members are involved in their creation. Increasingly complex legislation drives members' participation in ways unaccounted for through a sponsored bill progressing in the system. Scholars can return to the emphasis on committees in previous eras with modern tools such as textual analysis to gain a more robust appreciation of how committees affect legislating (Grimmer and Stewart 2013).

Amendments also provide members means to participate in potentially unexpected and unaccounted for ways. Members must now face their campaigns on a permanent basis, offering amendments beneficial to their electoral interests on

\section{Focusing on bills as the unit of effectiveness and efficiency can lead to overlooking important legislative battles and their changing contexts, looking instead at only the outcome of the strategies and fights.}

\section{LEGISLATING WITHIN AND OUTSIDE BILLS}

Congress provides members myriad ways to develop legislation, but members must make tradeoffs within and between each venue. Committees serving as the primary legislative development venue is not new to scholars, but attributing credit for participation is not always straightforward. Observing legislation develop in committee differed from my expectations in many ways. Committees are often thought to be either free-wheeling sessions or party-run enterprises, but members often worked from carefully planned individual strategies while only relying upon partisan procedural blocks when necessary. Members were far less deferential to apprenticeship and specialization norms than in earlier periods (Matthews 1960). As seen in the NDAA example above, members frequently engage in debates holding no relation to their assigned committees and insert language into legislation entirely outside their own committees' jurisdictions. This may result from changes in the style of legislation produced by Congress. Members work within larger bills to protect increasingly varied interests rather than having many narrowly targeted bills, making attributing success difficult at the bill-level.

The most intriguing tradeoff in developing legislation occurred where members spent their time working on legislative matters. Members have limited time and must choose where to place their emphasis. This often forced members to attend certain committee meetings over others with the deciding factor frequently a committee leadership role. Thus the back-and-forth of committee consideration plays out differently within and across committees. Bills within the same committee may not receive the same screens for content and passage. This can empower committee chairs by pushing a member to work through chair's mark or inserting language into bills not bearing her name. Votes are stacked on certain days to provide members a participation record, but members may not attend oversight hearings and meetings involving only bill development due to time pressures. Greater attention to committee functioning might provide new understandings of why and how bills develop, as well as multiple bills (Lee 2016). These amendments often address issues important to constituency or party bases, who reward a member for her tenacity in pursuing goals. Members are also pushed to offer amendments on legislation outside their specialized areas. The NDAA example above illustrates this, with all but two members offering amendments on a defense appropriations bill. Members know they cannot rely on legislation bearing their name to advance their interests. The permanent campaign and related publicity needs double this pressure, leading members to engage in fights outside their committee jurisdictions.

Decreasing use of joint chamber meetings to work out differences also incentivizes broader member participation. Rather than crafting legislation protecting their interests in conference committees, members must insert proposals into bills and ensure they survive each chamber's separate deliberations. Protecting interests now demands members insert themselves into debates broadly, with complex legislation moved back-and-forth between the chambers more likely than the traditional, relatively more controlled, bill negotiation process in conference. Scholars have begun observing the effects of bill-level complexity, and incorporating amending activity may more carefully model legislative politics (Hanson 2014; Roberts, Smith and Haptonstahl 2016).

While some changes in behavior result from current pressures, dismissing these trends as fleeting seems shortsighted (Sinclair 2016). Legislation will remain the vehicle by which ideas are passed into law, but this does not mean that the definition of a bill remains constant. Changes in how Congress functions push current members to behave differently than those before them. This may require a reevaluation of how we study policy proposals. Moving toward nuanced depictions of member goals and actions can provide a more detailed, accurate, depiction of legislative effectiveness and success.

\section{CONCLUDING THOUGHTS}

My goal in pursuing the fellowship was to observe Congress in its modern context. I expected this to orient around obstruction, delay, and objection. While I saw these actions, 
I also saw legislators working diligently to achieve their policy goals. These efforts appear in myriad ways, from bill sponsorship to inserting legislative text into bills seemingly unrelated to a member's interests. These insights are the most valuable portions of my time in the fellowship. Witnessing Congress at work, both to stall and pass legislation, provided a much richer understanding of modern lawmaking even in a Congress widely perceived as locked in legislative stalemate. These intuitions would have been difficult to discover as an outsider, and I hope to take the lessons learned into my work on the institution.

Perceptions of Congress orient around final passage votes and public laws, but this does not encompass the entire legislative process. Members react to their legislative environment, shifting behavior to best correspond with potential success. Legislative rules change across time, providing different incentives to members. The ability to freely submit, but not propose, amendments gives members the ability to position-take and advertise their policy interests within legislative vehicles already through the committee process. Changes in credit-claiming opportunities incentivize subtle ways to pursue district interests, often in bills not sponsored by a member.

The increasing difficulties in moving individual bills through the legislative process changes observable outcomes. Subtle tactics are more common than before, but the nature of legislation itself changes as well. If bills passed further through the system resemble the NDAA, then we run the risk of misidentifying success when only looking at final passage. Members target individual proposals within legislation, viewing both their inclusion in the bill and its passage as a success. Tying provisions to specific members is an arduous task, but scholars such as Wilkerson, Smith, and Stramp (2015) have begun the process. Legislators view these provisions as evidence of efficiency and effectiveness, and scholars should follow suit.

While an unproductive Congress through counting confirmations and passed legislation, the 114th Congress also illustrated its effectiveness. My experience showed a changing legislature. Legislation may still be the means through which ideas become law, but effective members do not focus only on passing their own sponsored bills. Legislators have acknowledged the changing nature of legislation and work toward their goals in new ways. The modern Congress meets in a quickly changing legislative world, and understanding success and efficiency requires following members through their actions.

\section{REFERENCES}

Ainsworth, Scott, and Douglas Hanson. 1996. "Bill Sponsorship and Legislative Success Among Freshmen Senators, 1954-1986." The Social Science Journal 33 (2): 211-21.

Grimmer, Justin, and Brandon M. Stewart. 2013. "Text as Data: The Promise and Pitfalls of Automatic Content Analysis Methods for Political Texts." Political Analysis 21 (3): 267-97.

Hanson, Peter C. 2014. "Abandoning the Regular Order: Majority Party Influence on Appropriations in the US Senate." Political Research Quarterly 67 (3): 519-32.

Kelly, Nathan J., and J. Tobin Grant. 2008. "Legislative Productivity of the US Congress, 1789-2004." Political Analysis 16 (3): 303-23.

Krutz, Glen. 2001. Hitching a Ride: Omnibus Legislating in the US Congress. Columbus: Ohio State University Press.

Lee, Frances. 2016. Insecure Majorities: Congress and the Perpetual Campaign. Chicago: University of Chicago Press.

Mann, Thomas E., and Norman J. Ornstein. 2006. The Broken Branch: How Congress is Failing America and How to Get it Back on Track. New York: Oxford University Press.

Matthews, Donald R. 1960. United States Senators and Their World. Chapel Hill: University of North Carolina Press.

Roberts, Jason, Steven Smith, and Stephen Haptonstahl. 2016. "The Dimensionality of Congressional Voting Reconsidered." American Politics Research 44 (5): 794-815.

Sinclair, Barbara. 2016. Unorthodox Lawmaking: New Legislative Processes in the US Congress. $5^{\text {th }}$ ed. Washington, DC: CQ Press.

Volden, Craig, and Alan E. Wiseman. 2014. Legislative Effectiveness in the United States Congress: The Lawmakers. New York: Cambridge University Press.

Wilkerson, John, David Smith, and Nicholas Stramp. 2015. "Tracing the Flow of Policy Ideas in Legislatures: A Text Reuse Approach." American Journal of Political Science 59 (4): 943-56.

Woon, Jonathan. 2008. "Bill Sponsorship in Congress: The Moderating Effect of Agenda Positions on Legislative Proposals." Journal of Politics 70 (1): 201-16. 